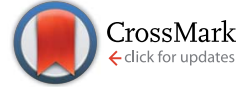

Cite this: RSC Adv., 2016, 6, 41568

\title{
A hybrid macrocyclic anion receptor exploiting the pyrrole-2,5-diacetamide unit $\uparrow$
}

\author{
Janusz Jurczak, ${ }^{\star}$ Pawel Dydio,ł Pawel Stepniak and Tomasz Zielinski§ \\ We report the synthesis of both macrocyclic and linear derivatives of pyrrole-2,5-diacetic bisamides, and \\ the studies of their anion binding properties, which are further compared with the properties of similar \\ derivatives bearing dipicolinic or isophthalic moieties. The new macrocyclic compound built on \\ pyrrole-2,5-diacetic bisamide was found to be an efficient receptor for $\mathrm{H}_{2} \mathrm{PO}_{4}{ }^{-}$and $\mathrm{PhCOO}^{-}$, even in \\ DMSO $-d_{6}+0.5 \% \mathrm{H}_{2} \mathrm{O}(\mathrm{v} / \mathrm{v})$, with changed relative selectivity toward a series of anions with respect to its \\ parental analogues. The anion binding properties of the linear derivatives of pyrrole-2,5-diacetic \\ bisamide, in turn, were found to strongly depend on the $\mathrm{p} K_{\mathrm{a}}$ of the amide $\mathrm{NH}$ protons, which can be \\ modulated through the introduction of various substituents.
}

Received 4th March 2016

Accepted 18th April 2016

DOI: $10.1039 / c 6 r a 05804 c$

www.rsc.org/advances pyrrole unit can act only as a donor, diminishing the risk of formation of intramolecular hydrogen bonding, unfavorable for anion binding. ${ }^{6}$ Consequently, pyrrole derivatives have attracted particular attention, with various linear and cyclic structures being explored as potential anion receptors. ${ }^{7}$ Alternatively, the pyrrole moiety has been used as a scaffold bearing additional hydrogen bond donors. ${ }^{8}$ This strategy has led to the formation of efficient and selective linear anion receptors, such as pyrrole2,5-dicarboxyamides ${ }^{9}$ and pyrrole-2,5-diacetamides. ${ }^{10}$

The macrocyclic topology of putative receptors allows many $\mathrm{H}$-bonding sites to be gathered in close proximity and arranged in a convergent manner, as required for effective host-guest interactions. Previously, we have shown that macrocyclic tetraamides, such as $\mathbf{1}$ and $\mathbf{2}$ (Fig. 1), are superior anion receptors over their linear analogues. ${ }^{11}$ We also found that the dipicolinic amide moiety, while itself interacting rather weakly with anionic guests, serves as a powerful unit in preorganizing hydrogen bonding sites. ${ }^{12}$ For instance, hybrid macrocycle 3, containing dipicolinic and isophthalic subunits, is a better anion receptor than both its parental congeners 1 and 2 (Fig. 1). We envisioned that introducing additional hydrogen bonding groups to such receptors may have the result of both strengthening the host-guest interaction and modulating the relative selectivity toward different anionic guest species. Here, we report on the synthesis and anion binding properties of hybrid receptor 4 which combines the potency of both dipicolinic amide and pyrrole-2,5-diacetamide building blocks, having a macrocyclic cavity of the same size as receptors 1-3 (20-membered ring). $\uparrow$

I Synthetic attempts to obtain the analogues of 4 that contain the pyrrole-2,5-dicarboxyamide unit in place of the pyrrole-2,5-diacetamide moiety were previously unsuccessful, hindering the evaluation of such putative anion receptors; for details, see: T. Zielinski, $\mathrm{PhD}$ Thesis, Institute of Organic Chemistry, Polish Academy of Sciences, Warsaw, 2006. 
<smiles>O=C1NCCCNC(=O)c2cccc(n2)C(=O)NCCCNC(=O)c2cccc1n2</smiles>

1

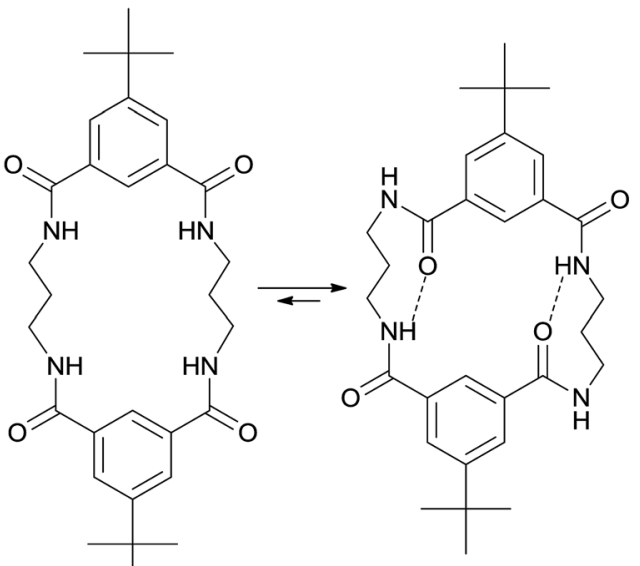

2<smiles></smiles>

3<smiles>O=C1Cc2ccc([nH]2)CC(=O)NCCNC(=O)c2cccc(n2)C(=O)NCCN1</smiles>

4

Fig. 1 20-Membered macrocyclic compounds 1-4.

\section{Results and discussion}

As shown in Scheme 1, the desired macrocyclic compound 4 was readily synthesized from known pyrrole-2,5-diacetic dimethyl ester (5). ${ }^{\mathbf{1 3}}$ Diester $\mathbf{5}$ was reacted with ethylenediamine to form diamide $\mathbf{6}$, which was then subjected to cyclization with dipicolinic methyl diester (7). The reaction proceeded very slowly in methanol, but when 1,8diazabicycloundec-7-ene (DBU) was added, the desired tetraamide 4 was formed with $15 \%$ yield within 2 weeks.

In addition, we prepared acyclic derivative $8 \mathbf{a}$ by simple amidation of diester $\mathbf{5}$ with $n$-butylamine, and also its $\mathbf{8 b}$

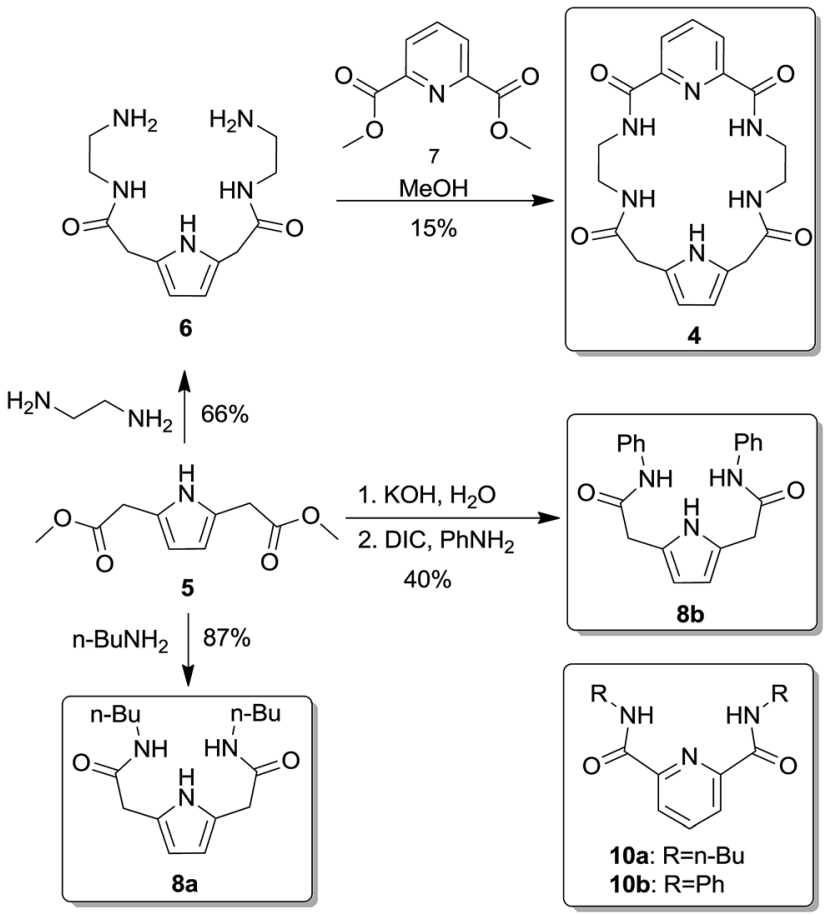

Scheme 1 Synthesis of macrocyclic receptor 4 and linear receptors 8. analogue by a two-step procedure (hydrolysis to diacid $\mathbf{9}$, followed by amidation with aniline and DIC) (Scheme 1).

Linear receptors $\mathbf{8 a}$ and $\mathbf{8 b}$ as well as dipicolinic acid bisamides (10a-b) (Scheme 1) were evaluated in terms of the relative contribution of the two aromatic moieties in receptor 4 (the dipicolinic amide and pyrrole-2,5-diacetamide building blocks) to its binding properties. Furthermore, this allowed the influence of the macrocyclic topology of $\mathbf{4}$ on its anion binding properties to be estimated. Finally, we compared binding properties of receptors $\mathbf{4}$ and $\mathbf{1 1}$ (Fig. 2) which allowed us to abstract contribution of topological differences of hydrogen bond donors position and assess role of the pyrrole moiety.

The anion binding measurements of the putative receptors were carried out in DMSO- $\mathrm{d}_{6}+0.5 \% \mathrm{H}_{2} \mathrm{O}(\mathrm{v} / \mathrm{v})$, using the ${ }^{1} \mathrm{H}$ NMR titration technique, with appropriate TBA salts as sources of anions. The association constants $\left(K_{\mathrm{a}}\right)$ measured for $\mathbf{8 a}$ and $\mathbf{8 b}$ were substantially higher than those of dipicolinic bisamide 10, showing that the pyrrolediacetamide is a superior building block over the dipicolinic moiety for the construction of linear receptors (Table $\mathbf{1}$ ). Receptor $\mathbf{8 b}$, bearing phenyl substituents instead of the $n$-butyl groups of $\mathbf{8 a}$, binds anions with three-fold higher $K_{\mathrm{a}}$.

The macrocyclic topology of $\mathbf{4}$, by contrast, imposes a conformation suitable for the anion binding process, with all amide and pyrrole protons convergent. This structure led to a 70 -fold higher $K_{\mathrm{a}}$ for chlorides in comparison to $K_{\mathrm{a}}$ measured

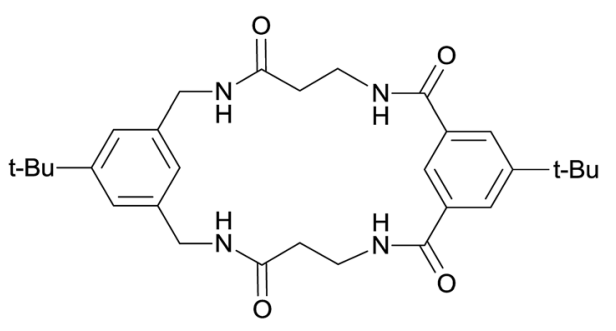

11

Fig. 2 Receptor 11 having analogous topology of $\mathrm{H}$-bond donors. 
Table 1 Stability constants $\left(\mathrm{M}^{-1}\right)$ for the formation of $1: 1$ complexes of $1-4,8 a-b, 10 a-b$ and 11 with various anions ${ }^{a}$

\begin{tabular}{llllllllll}
\hline & $\mathbf{1}^{b, c}$ & $\mathbf{2}^{d}$ & $\mathbf{3}^{e}$ & $\mathbf{4}$ & $\mathbf{8 a}$ & $\mathbf{8 b}$ & $\mathbf{1 0 a}$ & $\mathbf{1 0 b}$ & $\mathbf{1 1}^{d}$ \\
\hline $\mathrm{PhCOO}^{-}$ & 2283 & 601 & 3612 & 260 & 31 & 87 & 6.3 & 4.2 & $\mathrm{nd}^{g}$ \\
$\mathrm{H}_{2} \mathrm{PO}_{4}{ }^{-}$ & 7410 & $-f$ & $>8000$ & 617 & 108 & 577 & 12 & 12 & 327 \\
$\mathrm{Cl}^{-}$ & 1930 & 378 & 2148 & 204 & 3 & 8 & $<5$ & $<5$ & 29 \\
$\mathrm{Br}^{-}$ & 150 & $<5$ & 175 & 8 & $<5$ & $<5$ & $\mathrm{nd}^{g}$ & $<5$ & $\mathrm{nd}^{g}$
\end{tabular}

${ }^{a}$ Measured in DMSO- $\mathrm{d}_{6}+0.5 \% \mathrm{H}_{2} \mathrm{O}$. TBA salts were used as anion sources, uncertainties $<10 \%$. ${ }^{b}$ Measured in DMSO- $\mathrm{d}_{6} .{ }^{c}$ Ref. $11 a$. ${ }^{d}$ Ref. 11c. ${ }^{e}$ Ref. 12. ${ }^{f}$ Data did not fit $1: 1$ model. ${ }^{g}$ Not determined.

for $\mathbf{8 a}(c f$. Table 1). Binding to both benzoate and dihydrogen phosphate follows a similar tendency, with about one order of magnitude higher $K_{\mathrm{a}}$ 's for macrocyclic $\mathbf{4}$ as compared with linear 8a. Interestingly, bromides are weakly bound by receptor 4, indicating that such macrocycles are not planar, but rather form bent conformations which allow interaction with larger guests. This is supported by crystal structure analysis carried out for complexes of analogous molecules, were diaromatic macrocycles often form bent $\pi$-stacked structures. ${ }^{11 b}$

Comparison of the binding properties of macrocycle 4 with those of previously evaluated receptors 1-3 shows that the presence of the pyrrole unit modifies the relative selectivity for binding of different anions (Table 1). Interestingly, the incorporation of the additional binding site - the pyrrole NH proton does not result in increased association constants of receptor 4. On the contrary, receptor 4 binds anions with about one order of magnitude lower $K_{\mathrm{a}}$ 's than receptors 1-3. Hybrid dipicolinicisophtalic derivative 3 remains the most efficient receptor of this type. However, comparison of $\mathbf{4}$ with more structurally related macrocycle $\mathbf{1 1}^{11 c}$ shows that the additional hydrogen bonding $\mathrm{NH}$ group not only modifies the relative selectivity but also leads to a substantial increase in the binding of the chloride anion, with a 10 -fold higher $K_{\mathrm{a}}$.

Finally, in order to compare the binding properties of linear receptors 8 with the analogues obtained previously by Gale and coworkers, ${ }^{10}$ we performed additional titrations in $\mathrm{MeCN}-\mathrm{d}_{3}$ (Fig. 3 and Table 2). As could be expected, ${ }^{14}$ binding constants measured in acetonitrile- $\mathrm{d}_{3}$ are higher than those measured in DMSO- $\mathrm{d}_{6}$. Compound $\mathbf{8 b}$ binds chlorides with the highest $K_{\mathrm{a}}$ in this series of receptors. We found that the trend of increasing strength of the host-guest interaction follows the increasing acidity of the NH amide proton (defined by the chemical shifts found in ${ }^{1} \mathrm{H}$ NMR spectra) in the order: alkyl, benzyl, and phenyl

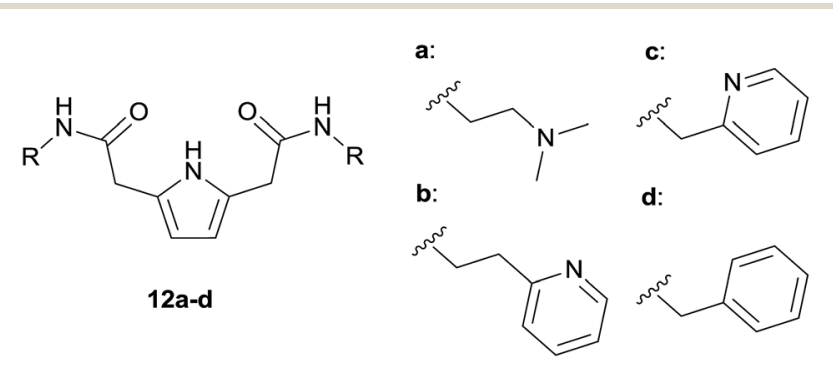

Fig. 3 Receptors used investigated by Gale and coworkers. ${ }^{10}$
Table 2 Stability constants $\left(M^{-1}\right)$ for the formation of $1: 1$ complexes of $8 a-b$, and $12 a-d$ with various anions ${ }^{a}$

\begin{tabular}{lllllll}
\hline & $\mathbf{8 a}$ & $\mathbf{8 b}$ & $\mathbf{1 2 a}^{b}$ & $\mathbf{1 2 b}^{b}$ & $\mathbf{1 2 c}^{b}$ & $\mathbf{1 2 d}^{b}$ \\
\hline $\mathrm{PhCOO}^{-}$ & 870 & 4150 & 1450 & 3370 & 5270 & 2500 \\
$\mathrm{Cl}^{-}$ & 96 & 580 & 135 & 150 & 190 & 190
\end{tabular}

${ }^{a}$ Measured in $\mathrm{CD}_{3} \mathrm{CN}$. TBA salts were used as anion sources, uncertainties $<10 \%$. ${ }^{b}$ Ref. 10.
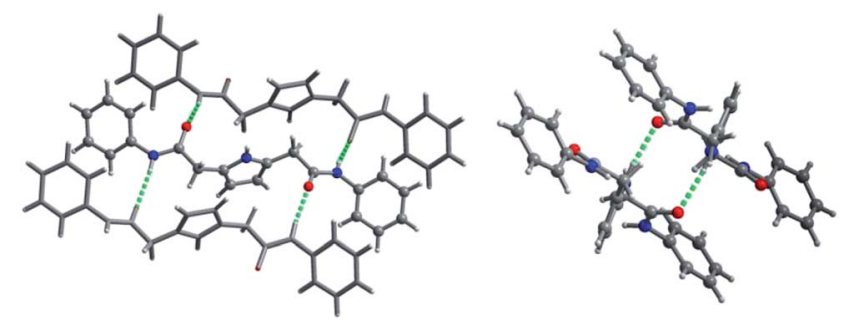

Fig. 4 X-ray structure of receptor $8 \mathrm{~b}$.

amide derivatives. Similar trends were observed in benzoate anion binding, which was bound the weakest by aliphatic derivative $\mathbf{8 a}$, and the strongest by phenyl derivative $\mathbf{8 b}$ and 2-pyridylmethylene derivative 12c, with $4150 \mathrm{M}^{-1}$ and $5270 \mathrm{M}^{-1}$ association constants, respectively.

In order to confirm our rationalization of the linear binding system, we performed crystal structure analysis of receptor $\mathbf{8 b}$. This showed that amide groups of the linear receptors are not coplanar with the pyrrole ring, but adopt the anti-anti conformation (Fig. 4). In consequence, contrary to its dipicolinic analogue (10), receptor $\mathbf{8 b}$ is not pre-organized for anion binding, hence the binding process requires a conformational change to adopt a pseudo syn-syn arrangement.

\section{Summary}

In conclusion, we have synthesized and studied the anion binding properties of both linear and macrocyclic receptors that incorporate the pyrrole-2,5-diacetamide building block. The linear receptors revealed relatively strong affinity for anions even in demanding solvents, e.g. DMSO $+0.5 \% \mathrm{H}_{2} \mathrm{O}$. The anion affinity of the linear pyrroleamide receptors strongly depends on the acidity of the amide NH protons, which can be controlled by different substitution of the side amide groups. The hybrid macrocyclic receptor constructed from both dipicolinic and pyrrole-2,5-diacetamidic building blocks showed superior affinity for anions as compared to the simple linear receptors, but inferior affinity as compared to the other hybrid receptors of this class. Overall, therefore, pyrrole-2,5-diacetamide further expands the repertoire of building blocks for the construction of linear and macrocyclic anion binding receptors.

\section{References}

1 (a) M. E. Moragues, R. Martínez-Máñez and F. Sancenón, Chem. Soc. Rev., 2011, 40(5), 2593-2643; (b) P. A. Gale and 
T. Gunnlaugsson, Chem. Soc. Rev., 2010, 39(10), 3595; (c)

B. P. Hay, Chem. Soc. Rev., 2010, 39(10), 3700-3708; (d) P. A. Gale, Chem. Soc. Rev., 2010, 39(10), 3746.

2 (a) N. Busschaert, C. Caltagirone, W. Van Rossom and P. A. Gale, Chem. Rev., 2015, 115(15), 8038-8155; (b) P. Dydio, R. J. Detz, B. de Bruin and J. N. H. Reek, J. Am. Chem. Soc., 2014, 136, 8418-8429; (c) P. Dydio, M. Ploeger and J. N. H. Reek, ACS Catal., 2013, 3, 2939-2942; (d) P. Dydio, R. J. Detz and J. N. H. Reek, J. Am. Chem. Soc., 2013, 135, 10817-10828; (e) P. Dydio and J. N. H. Reek, Angew. Chem., Int. Ed., 2013, 52, 3878-3882; (f) P. Dydio, C. Rubay, T. Gadzikwa, M. Lutz and J. N. H. Reek, J. Am. Chem. Soc., 2011, 133, 17176-17179; (g) P. Dydio, W. I. Dzik, M. Lutz, B. de Bruin and J. N. H. Reek, Angew. Chem., Int. Ed., 2011, 50, 396-400.

3 (a) F. Zapata, L. Gonzalez, A. Caballero, I. Alkorta, J. Elguero and P. Molina, Chem.-Eur. J., 2015, 21, 9797-9808; (b) I. Saha, J. T. Lee and C.-H. Lee, Eur. J. Org. Chem., 2015, 2015, 38593885; (c) S. J. Edwards, H. Valkenier, N. Busschaert, P. A. Gale and A. P. Davis, Angew. Chem., Int. Ed., 2015, 54, 4592-4596; (d) G. Alibrandi, V. Amendola, G. Bergamaschi, L. Fabbrizzi and M. Licchelli, Org. Biomol. Chem., 2015, 13, 3510-3524; (e) L. Fabbrizzi and A. Poggi, Chem. Soc. Rev., 2013, 42, 1681-1699; (f) J. Cai and J. L. Sessler, Chem. Soc. Rev., 2014, 43, 6198; $(g)$ S. K. Kim, V. M. Lynch and J. L. Sessler, Org. Lett., 2014, 16, 6128-6131; (h) J. Y. C. Lim and P. D. Beer, Chem. Commun., 2015, 51, 3686-3688.

4 (a) S. W. Robinson, C. L. Mustoe, N. G. White, A. Brown, A. L. Thompson, P. Kennepohl and P. D. Beer, J. Am. Chem. Soc., 2015, 137(1), 499-507; (b) A. E. Hargrove, S. Nieto, T. Zhang, J. L. Sessler and E. V. Anslyn, Chem. Rev., 2011,
111(11), 6603-6782; (c) P. A. Gale, Acc. Chem. Res., 2011, 44(3), 216-226; (d) J. Cai and J. L. Sessler, Chem. Soc. Rev., 2014, 43, 6198-6213.

5 V. Amendola, L. Fabbrizzi and L. Mosca, Chem. Soc. Rev., 2010, 39, 3889.

6 T. Zieliński, P. Dydio and J. Jurczak, Tetrahedron, 2008, 64, 568-574.

7 D. S. Kim and J. L. Sessler, Chem. Soc. Rev., 2015, 44(2), 532546.

8 (a) V. Amendola, L. Fabbrizzi and L. Mosca, Chem. Soc. Rev., 2010, 39(10), 3889-3915; (b) J. W. Steed, Chem. Soc. Rev., 2010, 39(10), 3686; (c) V. Blažek Bregović, N. Basarić and K. Mlinarić-Majerski, Coord. Chem. Rev., 2015, 295, 80-124.

9 (a) T. Zieliński, M. Kedziorek and J. Jurczak, Chem.-Eur. J., 2007, 14, 838-846; (b) L. S. Evans, P. A. Gale, M. E. Light and R. Quesada, New J. Chem., 2006, 30, 1019.

10 R. Li, L. S. Evans, D. S. Larsen, P. a. Gale and S. Brooker, New J. Chem., 2004, 28, 1340.

11 (a) M. J. Chmielewski and J. Jurczak, Tetrahedron Lett., 2004, 45(31), 6007-6010; (b) M. J. Chmielewski and J. Jurczak, Chem.-Eur. J., 2005, 11, 6080-6094; (c) M. J. Chmielewski and J. Jurczak, Chem.-Eur. J., 2006, 12, 7652-7667.

12 M. J. Chmielewski and J. Jurczak, Tetrahedron Lett., 2005, 46, 3085-3088.

13 (a) W. Flitsch and F.-J. Lüttig, Liebigs Ann. Chem., 1987, 893; (b) F. Johnson, K. G. Paul, D. Favara, R. Ciabatti and U. Guzzi, J. Am. Chem. Soc., 1982, 104, 2190; (c) R. Li, D. S. Larsen and S. Brooker, New J. Chem., 2003, 27, 1353.

14 P. Dydio, D. Lichosyt and J. Jurczak, Chem. Soc. Rev., 2011, 40, 2971. 